\title{
研究論文
}

\section{小麦フスマを基質とする水素発䤏に扑る初期 $\mathrm{pH}$ 及び 培養温度の影響}

\section{要旨}

神奈川県内の小麦製粉事業者から入手した小麦フスマを基質として，植菌せずに初期 $\mathrm{pH}$ を，5，6，7， 培養温度を $25 ， 35 ， 45^{\circ} \mathrm{C}$ と段階的に設定して回分培養による水素発酵を実施し, 初期 $\mathrm{pH}$ 及び培養温度の水 素生成や小麦フスマ成分の分解性に対する影響を検討した。 その結果, 水素収率は, $25^{\circ} \mathrm{C}$ 及び初期 $\mathrm{pH} 6$ で最 大值（80.4ml/g-VS）を示すことが明らかとなったままた，小麦フスマ中の成分の培養条件による分解率の 違いについて調査したところ, 全炭水化物は $35^{\circ} \mathrm{C}$ 及び初期 $\mathrm{pH} 7$ において最大の分解率 (89.2\%), 全蛋白質 については $25^{\circ} \mathrm{C}$ 及び初期 $\mathrm{pH} 4$ において最大の分解率（54.1\%），脂肪については $45^{\circ} \mathrm{C} 及 ひ ゙$ 初期 $\mathrm{pH} 5$ において 最大の分解率（51.2\%）をそれぞれ示すことが明らかとなった.

キーワード: 小麦フスマ, 水素発酵, 初期 $\mathrm{pH}$, 培養温度, 分解性

\section{1.はじめに}

小麦製粉業界においては，製粉事業から発生する有 機性残さとしてフスマが年間約120万 $\mathrm{t}$ 発生しており, そのリサイクル用途としては家畜飼料や堆肥化が現在 多くの事業者において実施されている。しかし，家畜 飼料においては需給バランスの変動により売買価格が 不安定であることや，堆肥化では需要に季節変動があ ることや畑地と製粉事業者との立地上の離隔による輸 送コストの問題がある。またりサイクルされない残さ については焼却処分されており，新たな有効利用の用 途が求められている.

一方，有機性廃棄物の有効利用がバイオマス・ニッ ポン総合戦略等の政策的視点から求められており, こ のバイオマスを有効利用する方策の一つとして水素発 酵が近年注目されている，バイオマスとして小麦フス マを水素発酵する場合，種菌を植種せずに自生してい る菌を利用して発酵できることが既報において報告さ れている ${ }^{1)}$ （しかし小麦フスマの水素発酵における $\mathrm{pH}$ や培養温度の影響について検討した研究事例は少 ない. したがって, 将来的に小麦フスマの水素発酵を
事業化するためには，このような影響因子の十分な検 討が必要である.

本研究では，植菌せずに小麦フスマを水素発酵して 初期 $\mathrm{pH}$ 及び培養温度の水素生成や小麦フスマ成分の 分解性に対する影響を検討し, 種々の知見を得たので, これらの結果について報告する。

\section{2. 実験方法}

実験は，神奈川県内の小麦製粉事業者から入手した 小麦フスマを基質とする回分培養試験とした。実験に 用いた小麦フスマの組成分析結果を表 1 に示す.

表 1 小麦フスマの組成分析結果

\begin{tabular}{c|c}
\hline 組 成 & 割合 $(\%)$ \\
\hline TS & 87.4 \\
\hline VS & 82.7 \\
\hline 水 分 & 12.6 \\
\hline 灰 分 & 4.7 \\
\hline 炭水化物 & 55.6 \\
\hline 蛋白質 & 21.2 \\
\hline 脂 質 & 5.9 \\
\hline
\end{tabular}




\section{1 初期 $\mathrm{pH}$ 及び培養温度による影響}

回分実験装置を図ー1に示す，発酔槽は硬質ガラス 製のバイアルビン（容積 $1.25 \ell ）$ を用い，小麦フスマ を $5 \mathrm{~g}$ (湿重量) とイオン交換水 $1 \ell$ を入れ，初期 $\mathrm{pH}$ t $4,5,6,7$, 培養温度を $25,35,45^{\circ} \mathrm{C}$ と段階 的に設定して恒温水槽内で一定温度に維持しながら培 養温度 $25^{\circ} \mathrm{C}$ 及び $35^{\circ} \mathrm{C}$ は 4 日間, 培養温度 $45^{\circ} \mathrm{C}$ は 8 日間 培養を行い，培養期間中の発生ガス， $\mathrm{pH}, \mathrm{ORP}$ 及び 発酵終了後の培養液中の炭水化物, 蛋白質, 脂質, VFA 濃度を分析した。ここで発生ガス量については, 図ー 1 に示されるガス捕集装置を用いて水上置換法に より測定し，標準状態 $\left(0{ }^{\circ} \mathrm{C} ， 1 \mathrm{~atm}\right)$ に換算した. また発生ガスをガス採取口よりガスタイトシリンジで サンプリングしてガス組成を分析した。なお，初期 $\mathrm{pH}$ は $\mathrm{HCl}(1 \mathrm{~N})$ で調整した。

\section{2 基質, 発生ガス及び培養液の分析方法}

TS, VS 分析は下水試験方法 ${ }^{2)}$ に準拠して分析した.

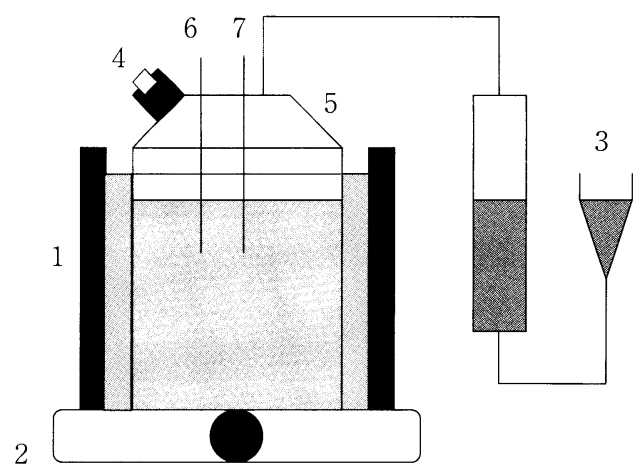

1. 恒温槽, 2 . 攪拌装置, 3 . ガス捕集装置，4. ガス採取口，

5 . 発酵槽, $6 . \mathrm{pH}$ 電極, $7 . \mathrm{ORP}$ 電極

図一１＼cjkstart培養装置及びガス捕集装置
炭水化物はグルコースを標準物質としてフェノール硫 酸法, 蛋白質はアルブミンを標準物質として Modified Lowry Protein Assay Reagent Kit (PIERCE), 脂質 は含水クロロホルムーメタノール混液抽出法にて分析 した.ここで培養液中の炭水化物及び蛋白質分析につ いては，培養液を3000rpm で10分間遠心分離（Hitachi 05PR-22）後，上澄みを溶解性成分の分析に用い，遠 心分離前の培養液の分析結果と溶解性成分の分析結果 の差を不溶性成分の分析値とした。また発生ガス中の 水素, メタン, 炭酸ガスの割合は TCD ガスクロマトグ ラフ (HewlettPackard HP6890GC カラム : Molecular Sieve13A キャリアガス：He）で，培養液中の VFA 濃度 (ギ酸, 乳酸, 酢酸, プロピオン酸, 酪酸, 吉草酸) は 高速液体クロマトグラフィー（ポンプ：Shimazu LC$6 \mathrm{~A}$, 検出器: Shimazu SPD-6A, カラム : Shim-pack SCR-101H，移動相： $5 \mathrm{mM}$ 過塩素酸) で分析した. 発酵液の $\mathrm{pH}$ は HORIBA 製 D-52及び $\mathrm{pH}$ 複合電極 （9621-10D）で測定した。また発酵液の ORP は HORIBA 製D-52及びORP測定用金属電極 (9300-10D) を用いて測定し，標準水素電極を基準電極とした值に 換算した.

\section{3. 結果と考察}

\section{1 発生ガス分析結果}

\subsection{1 発生ガスの経時変化及び水素発生効率}

図一2に培養条件を変えた時の水素収率 $(=$ 有機物 量 (VS) $1 \mathrm{~g}$ 当たりの水素生成量 $(\mathrm{m} \ell)$ の最大值)を示 す。これより $25^{\circ} \mathrm{C}$ 及び初期 $\mathrm{pH} 6 て ゙ 80.4 \mathrm{ml} / \mathrm{g}-\mathrm{VS} （=66.5$ $\mathrm{ml} / \mathrm{g}$ ) と最大值を示すことが明らかとなった. $25^{\circ} \mathrm{C}$ で水素生成量が最大となる本研究での結果は，43〜

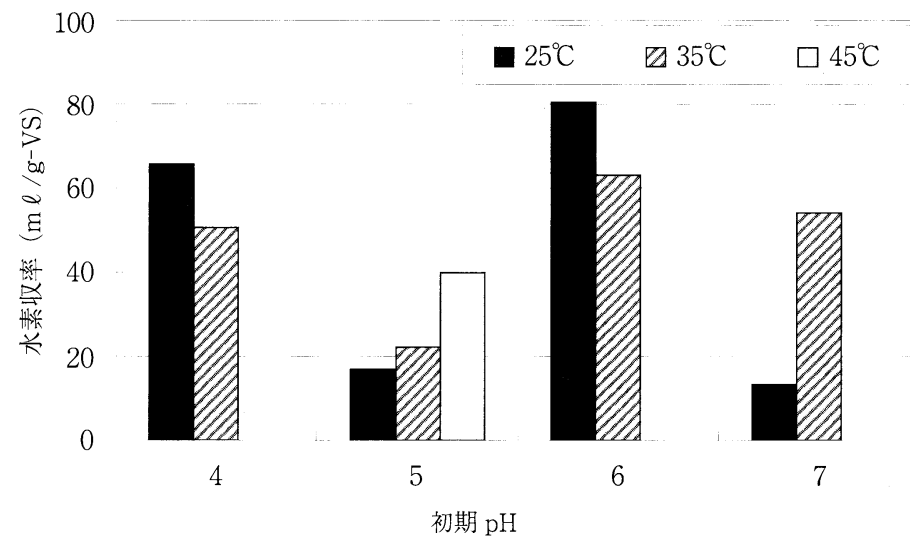

図一2 初期 $\mathrm{pH}$ 及び培養温度を変えたときの水素収率 
$45^{\circ} \mathrm{C}$ で水素生成量が最大を示した田口らの研究結果 ${ }^{1)}$ とは異なるものであった。また水素収率については田 口らの研究 ${ }^{1)}$ では $60 \mathrm{ml} / \mathrm{g}$ と報告されており, 本研究 で示された水素収率の最大值が $66.5 \mathrm{~m} \ell / \mathrm{g}$ に相当するこ とからほほ同等な值を示すことが明らかとなった。こ のように $25^{\circ} \mathrm{C}$ で水素生成が顕著に確認されたことは, 将来の実用化において水素発酵槽を加温する熱源を確 保する必要性が低いことを示唆している，なお，発酵 槽中の水素ガス濃度は水素ガス量の最大値を示した培 養条件である $25^{\circ} \mathrm{C}$ 及び初期 $\mathrm{pH} 6$ で最大值（35.6\%）を 示し, また全ての培養条件において炭酸ガスの発生が 確認されたが，メタンガスは確認されなかった。

図ー3に培養温度毎に水素生成量が最大を示した培 養条件である, $25^{\circ} \mathrm{C}$ 及び初期 $\mathrm{pH} 6,35^{\circ} \mathrm{C}$ 及び初期 $\mathrm{pH} 6,45^{\circ} \mathrm{C}$ 及び初期 $\mathrm{pH} 5$ での水素ガス量の経時変化を 示す．培養温度が高くなるほどに水素ガス量が最大と なる培養時間が長期化する傾向が観察された。この理 由としては，培養温度の上昇とともに水素生成と比較
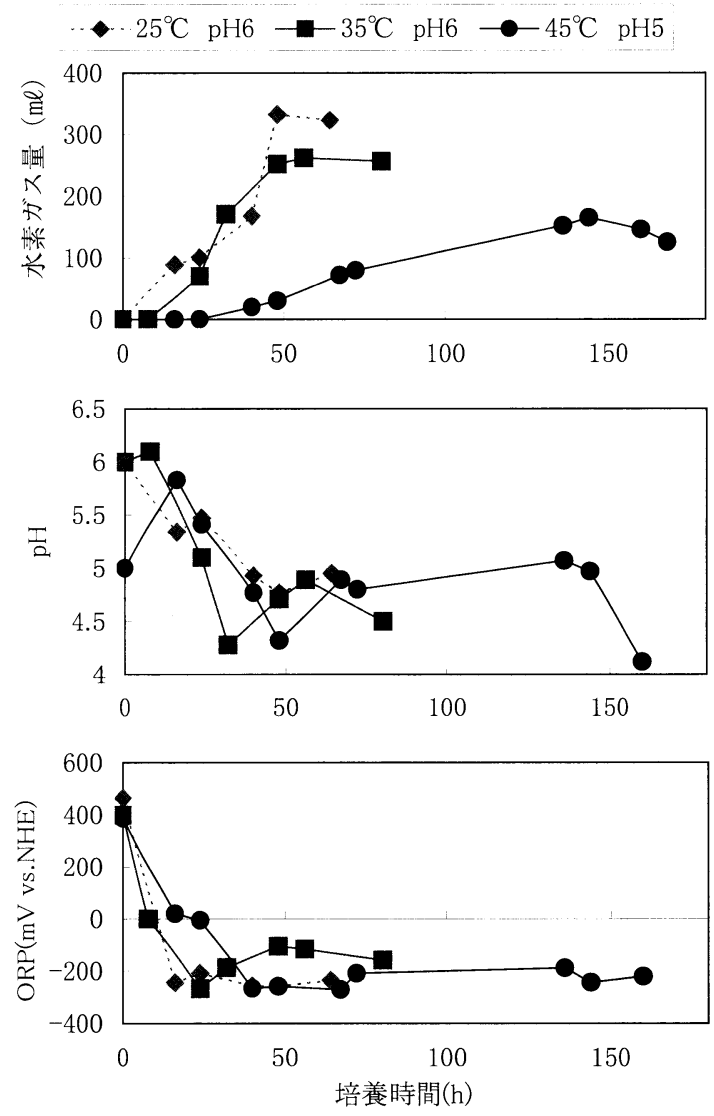

図-3 水素ガス量, $\mathrm{pH}$ 及び ORP の経時変化
して水素消費速度が増大したためと推察された。また $45^{\circ} \mathrm{C}$ 及び初期 $\mathrm{pH} 5$ において培養時間の後半では, 発 生した水素ガスが吸収される現象が観察された。これ は水素生成菌より世代時間の長い水素資化性細菌が関 与していると推察された。

\subsubsection{Gompertz 型式による解析}

Wuらの研究において, 回分培養における水素ガス 量の経時変化は以下に示す Gompertz 型式で良好に近 似されることが報告されている ${ }^{3)}$.

$$
H(t)=P \cdot \exp -\exp \left[\frac{R m \cdot e}{P}(\lambda-t)+1\right]
$$

$\mathrm{H}(\mathrm{t}): \mathrm{t}$ 時間経過後における水素ガス量 $(\mathrm{m} \ell), \mathrm{P}$ ： 水素生成ポテンシャル (me), Rm：最大水素生成速 度 $(\mathrm{m} \ell / \mathrm{h}), \mathrm{e}$ : 自然対数の底, $\lambda$ : 遅滞時間 $(\mathrm{h}), \mathrm{t}$ : 培養時間 $(\mathrm{h})$

本研究においても Wu らの研究 ${ }^{3)}$ と同様に実験結 果に対して Gompertz 型式を当てはめて P, Rm, $\lambda$ のそれぞれのパラメータを決定した。表 2 に Gompertz 型式による解析結果を示す，決定係数 $\mathrm{R}^{2}$ は 全て0.999以上を示し，実測值と Gompertz 型式によ る計算值は良好な相関を示した.またこの解析により， 水素生成ポテンシャル $\mathrm{P}$ は培養温度 $25^{\circ} \mathrm{C}$ 及び初期 $\mathrm{pH} 6$ で最大（339ml）となり，また最大水素生成速度 $\mathrm{Rm}$ は $35^{\circ} \mathrm{C}$ 及び初期 $\mathrm{pH} 4$ で最大 $(30.0 \mathrm{~m} / / \mathrm{h})$ となることが 明らかとなった。また遅滞時間 $\lambda$ は $25^{\circ} \mathrm{C}$ 及び初期 $\mathrm{pH} 5$ の時に最大 $(39.2 \mathrm{~h})$ となり, 最大水素生成速度 $\mathrm{Rm}$ は $25^{\circ} \mathrm{C}$ 及び $35^{\circ} \mathrm{C}$ で初期 $\mathrm{pH} 4$ の時に大きくなる傾向が 観察された。

\section{$3.2 \mathrm{pH}$ 及び ORP の経時変化}

\section{2 .1 水素生成量の大きい培養条件での $\mathrm{pH}$ 及び ORP の経時変化}

図ー 3 に培養温度毎に水素生成量が最大を示した培 養条件である， $25^{\circ} \mathrm{C}$ 及び初期 $\mathrm{pH} 6,35^{\circ} \mathrm{C}$ 及び初期 $\mathrm{pH} 6,45^{\circ} \mathrm{C}$ 及び初期 $\mathrm{pH} 5$ での $\mathrm{pH}$ 及び ORP の経時変 化を示す, $\mathrm{pH}$ については，水素発生開始前後に若干 低下した後に上昇する傾向が見られたが，最終的には 4.12４.95まで低下した．この $\mathrm{pH}$ の経時変化につい ては, $\mathrm{pH}$ の低下は有機酸の生成, $\mathrm{pH}$ の上昇はアミ ノ酸の分解による $\mathrm{NH}_{4}{ }^{+}$の生成の影響と推察された ${ }^{4)}$. またORPについては, 水素が発生している培養時間 中は - 105〜 - 270mVの嫌気状態を維持していること 
表 2 回帰分析結果

\begin{tabular}{c|c|ccc}
\hline 培養温度 & 初期 $\mathrm{pH}$ & $\mathrm{P}(\mathrm{m} \ell)$ & $\mathrm{Rm}(\mathrm{m} \ell / \mathrm{h})$ & $\lambda(\mathrm{h})$ \\
\hline & 4 & 274.8 & 23.9 & 14.7 \\
& 5 & 70.5 & 2.9 & 39.2 \\
$25^{\circ} \mathrm{C}$ & 6 & 339.0 & 10.0 & 10.2 \\
& 7 & 55.0 & 1.4 & 20.7 \\
\hline & 4 & 210.7 & 30.0 & 19.7 \\
$35^{\circ} \mathrm{C}$ & 5 & 96.2 & 6.1 & 11.7 \\
& 6 & 262.9 & 13.7 & 17.6 \\
& 7 & 227.2 & 9.7 & 9.4 \\
\hline $45^{\circ} \mathrm{C}$ & 5 & 165.8 & 2.4 & 35.2 \\
\hline
\end{tabular}

が明らかとなった：このことから，水素発酵の挙動を モニタリングするには ORP 測定が有効であることが 明らかとなった。

\section{2 .2 水素生成の有無による $\mathrm{pH}$ 及び ORP の経 時変化の違い}

図- 4 に $45^{\circ} \mathrm{C}$ ，初期 $\mathrm{pH} 5$ 及び 6 での $\mathrm{pH}$ 及び ORP の経時変化を示す，pHの経時変化については，培養 開始から48時間までに急激に低下した後若干上昇し， その後横ばいとなる挙動を双方とも示した．このこと から，水素生成の有無を $\mathrm{pH}$ の経時変化から判断する
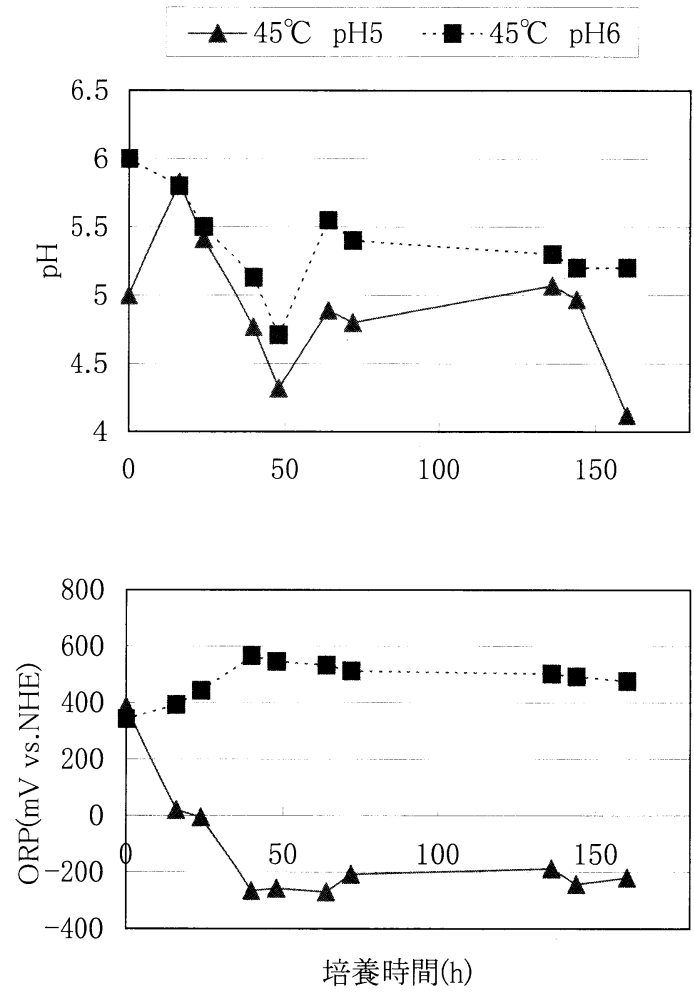

図ー4 $45^{\circ} \mathrm{C}$ 及び初期 $\mathrm{pH}$,6にたおける $\mathrm{pH}, \mathrm{ORP}$ の経時 変化
ことは困難と推察された，一方，ORP の経時変化に ついては，水素生成の確認された培養条件である初期 pH5の時には培養初期段階で $-270 \mathrm{mV}$ まで急激に低 下し，培養時間160時間においても $-220 \mathrm{mV}$ を維持し ていることが確認された。また水素生成の確認されな かった培養条件である初期 $\mathrm{pH} 6$ の時にはORPが $566 \mathrm{mV}$ まで上昇し培養時間160時間を経過しても $476 \mathrm{mV}$ と高い值を維持していることが明らかとなっ た。これより水素生成の有無を ORP 測定から間接的 に判断でき，また水素生成に適した ORP は $45^{\circ} \mathrm{C}$, pH5付近では-220〜 - 270mVであると推察された。

\section{3 培養液分析結果}

\subsubsection{VFA，最終 pH 及び最終 ORP 分析結果}

表 3 に発酢終了後の培養液中の有機酸, 最終 $\mathrm{pH}$ 及 び ORPの分析結果を示す．有機酸としては酢酸，酪

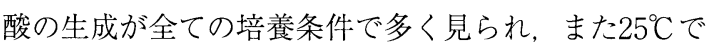
は乳酸， $45^{\circ} \mathrm{C}$ では蟻酸も若干生成していることが確認 された。しかし，プロピオン酸と吉草酸については全 ての培養条件で検出されなかった.

水素生成の多い条件では酢酸及び酪酸の生成が顕著 に見られるとVavilin ら，河野らの研究においては報 告されている ${ }^{5,6)}$ が，本研究においては水素生成のな い培養条件でも酢酸,酪酸の生成が見られることから, 同様の傾向は確認されなかった，炭水化物のみならず

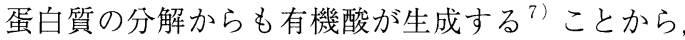
このような水素を生成しない代謝経路が本実験では関

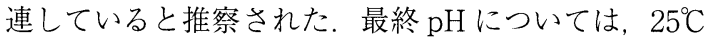
及び初期 $\mathrm{pH} 4,5,35^{\circ} \mathrm{C}$ 及び初期 $\mathrm{pH} 4,45^{\circ} \mathrm{C}$ 及び初 期 $\mathrm{pH} 4$ においては初期 $\mathrm{pH}$ を上回ったが，その他の培

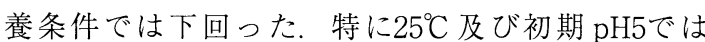
$\Delta \mathrm{pH}$ が-1.24と低く，これはVFA 濃度が381mg/ l と他の培養条件と比べて小さいことが影響したと考え られた，最終 ORP については，水素生成の確認され た培養条件では-268～86mVであり，これは水素生 成の確認されなかった培養条件での ORP 值（312 $476 \mathrm{mV})$ より明らかに低い值であることが確認され た。これより水素生成のモニタリング指標として最終 ORPの有効性が示唆された.

\subsection{2 炭水化物, 蛋白質及び脂質分析結果}

(1) 炭水化物分析結果

図一 5 に発酵前及び発酵終了後の培養液中の炭水化 物分析結果を示す。これより全炭水化物については $35^{\circ} \mathrm{C}$ 及び初期 $\mathrm{pH} 7$ において最も高い分解率（89.2\%） 
表 3 培養液中の VFA 濃度及び最終 $\mathrm{pH}$

\begin{tabular}{|c|c|c|c|c|c|c|c|c|c|c|c|c|}
\hline 培養温度 & \multicolumn{4}{|c|}{$25^{\circ} \mathrm{C}$} & \multicolumn{4}{|c|}{$35^{\circ} \mathrm{C}$} & \multicolumn{4}{|c|}{$45^{\circ} \mathrm{C}$} \\
\hline 初期pH & 4 & 5 & 6 & 7 & 4 & 5 & 6 & 7 & 4 & 5 & 6 & 7 \\
\hline 蟻酸 $(\mathrm{mg} / \mathrm{l})$ & ND & ND & ND & ND & ND & ND & ND & ND & 109 & 107 & 82 & 60.6 \\
\hline 䣷酸濃度 $(\mathrm{mg} / \mathrm{l})$ & 256 & 168 & 116 & 395 & 375 & 525 & 528 & 183 & 270 & 244 & 295 & 179 \\
\hline 乳酸濃度 $(\mathrm{mg} / \mathrm{l})$ & 31 & 27 & 89 & ND & 31 & ND & 25 & 44 & ND & ND & ND & ND \\
\hline 酪酸濃度 $(\mathrm{mg} / \mathrm{l})$ & 321 & 186 & 517 & 1021 & 613 & 563 & 404 & 872 & 730 & 669 & 672 & 543 \\
\hline VFA濃度 $(\mathrm{mg} / \mathrm{l})$ & 608 & 381 & 722 & 1416 & 1019 & 1088 & 956 & 1099 & 1109 & 1020 & 1049 & 783 \\
\hline 最終pH & 4.46 & 6.24 & 4.95 & 5.50 & 4.58 & 4.45 & 4.50 & 4.94 & 4.41 & 4.12 & 5.20 & 5.00 \\
\hline$\Delta \mathrm{pH}^{*}$ & -0.46 & -1.24 & 1.05 & 1.50 & -0.58 & 0.55 & 1.50 & 2.06 & -0.41 & 0.88 & 0.80 & 2.00 \\
\hline 最終ORP & -134 & -227 & -235 & -54 & 86 & -108 & -158 & -268 & 402 & -223 & 284 & 312 \\
\hline
\end{tabular}

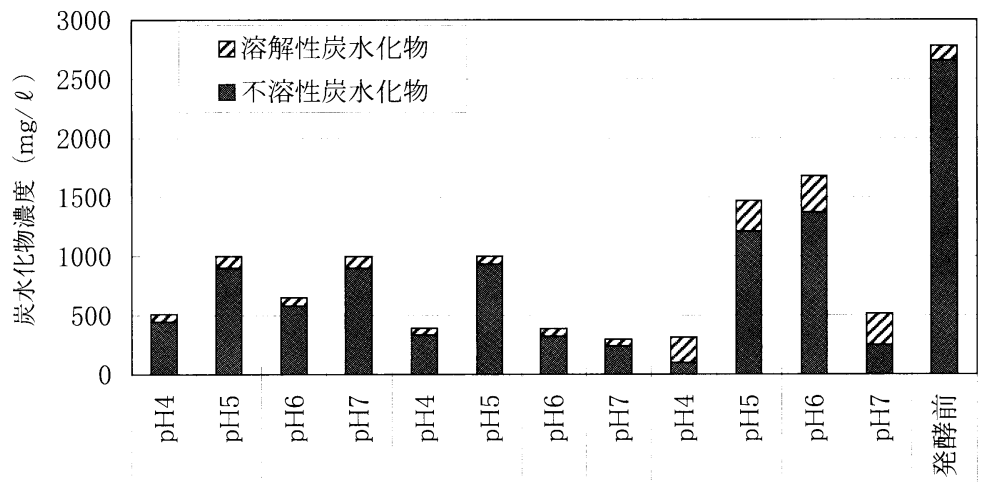

$25^{\circ} \mathrm{C}$

$35^{\circ} \mathrm{C}$

$45^{\circ} \mathrm{C}$

培養条件

図 -5 培養液中の不溶性及び溶解性炭水化物濃度

を示すことが明らかとなった．また溶解性，不溶性炭 水化物濃度については, $25^{\circ} \mathrm{C}, 35^{\circ} \mathrm{C}$ とに溶解性成分

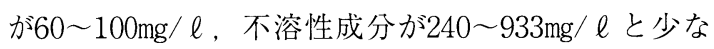

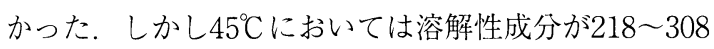
$\mathrm{mg} / \ell$ と高く, 不溶性成分については初期 $\mathrm{pH}$ による

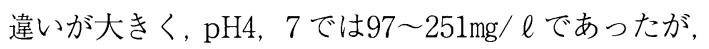
pH5， 6 では1208 1370mg/ $\ell$ と残存量が大きかった.

水野らの研究においては炭水化物の分解が水素生成 に直接的に関与するとされており ${ }^{8)}$ ，本研究結果にお いても，炭水化物消費量と水素生成量との間に相関が あるか検証を行った．図一6に消費された炭水化物の 割合と対応する培養条件での水素収率との相関を示

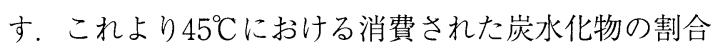
と水素生成量との相関は低かったものの, $25^{\circ} \mathrm{C}$ 及び $35^{\circ} \mathrm{C}$ では炭水化物消費量と水素生成量は概ね相関があ り, 低い培養温度における炭水化物の分解の水素生成 への直接的な関与が示唆された。

ここで, 水素ガスが消費された炭水化物のみから発 生したと仮定すると, 水素収率のヘキソース換算値 $(=$
ヘキソース $1 \mathrm{~mol}$ 当たりの水素発生量 $(\mathrm{mol}))$ は培養 温度 $25^{\circ} \mathrm{C}$, 初期 $\mathrm{pH} 6$ で最大 $\left(1.26 \mathrm{~mol}-\mathrm{H}_{2} / \mathrm{mol}\right.$-hexose $)$ となった。この值は水野らの研究 ${ }^{8)}$ で示されている 值 $(1.73 \mathrm{~mol} / \mathrm{mol}$-hexose) より小さいが, これについ ては, 水野らの研究では前培養した水素生成菌を植菌 しており，また基質として不溶性の粗成分を除去して 溶解性成分を多く含むフスマを発酵に用いているた め, 水素生成菌の水素生成能力と基質の分解性の差が 現れたと考えられた。

基質中の炭水化物が全て酢酸に変換されるとすると 理論的には水素が最大 $4 \mathrm{~mol}-\mathrm{H}_{2} / \mathrm{mol}$-hexose 生成す るが, 実際には酢酸以外の有機酸も生成することや還 元力も有機物に依存することから $2 \mathrm{~mol}-\mathrm{H}_{2} / \mathrm{mol}^{-}$ hexose 程度が限界とされる ${ }^{91}$. 小麦フスマ以外の有 機性廃棄物を基質とする水素発酵研究での既往の研究 で示されている水素収率のヘキソース換算值を列挙す ると，扔から $\left(2.54 \mathrm{~mol}-\mathrm{H}_{2} / \mathrm{mol}^{-h e x o s e}\right)^{10)}$, リンゴ $\left(2.76 \mathrm{~mol}-\mathrm{H}_{2} / \mathrm{mol} \text {-hexose }\right)^{11)}$, パン $\left(1.87 \mathrm{~mol}-\mathrm{H}_{2} / \mathrm{mol}^{-}\right.$ hexose $)^{11)}$, 廃糖蜜 $\left(2.5 \mathrm{~mol}-\mathrm{H}_{2} / \mathrm{mol} \text {-sucrose }\right)^{12)}$ となっ 


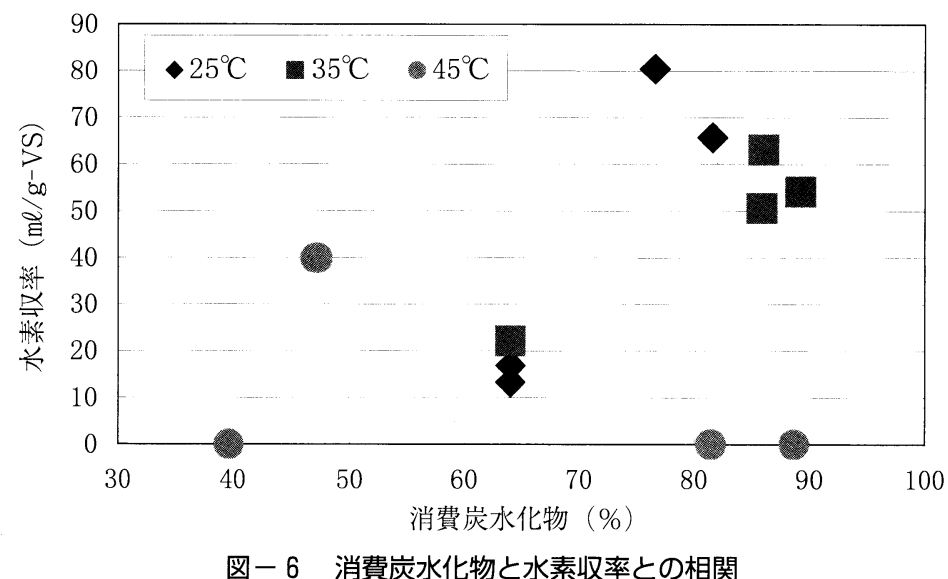

ており，本研究での小麦フスマの水素収率より大きい ことが明らかとなった。しかしこれらの研究では水素 生成菌を前培養して植菌する操作を必要とし，実用化 を考えると発酵プロセスが煩雑となる問題がある。一 方，小麦フスマの場合は自生している水素生成菌を利 用できるため，種菌を別に入手し前培養して植菌する 必要がないことや，基本的な培養条件（温度，初期 $\mathrm{pH}$ ）の調整のみで相当量の水素を回収可能であるこ とが本研究から明らかとなった。 よってこれらより, 小麦フスマを基質とする水素発酵の実用化に向けて簡 略化された培養システムを構築可能であることが示唆 された。

（2）蛋白質分析結果

図ー 7 に発酵前及び発酵終了後の培養液中の蛋白質 分析結果を示す。これより, 全蛋白質については培養 温度の低下とともに分解率が上昇し， $25^{\circ} \mathrm{C}$ 及び初期 pH4において最も高い分解率（54.1％）を示すことが 明らかとなった。またそれぞれの培養温度において， $25^{\circ} \mathrm{C}$ 及び初期 $\mathrm{pH} 4,35^{\circ} \mathrm{C}$ 及び初期 $\mathrm{pH} 6,45^{\circ} \mathrm{C}$ 及び初 期 $\mathrm{pH} 5$ で全蛋白質の分解率が最大となることが明ら かとなった. Breure らの研究に扔いては，蛋白質と してゼラチンを用いた時の分解率は $\mathrm{pH}$ を中性付近に 維持した時に最大になると示されている7 。本実験で は $25^{\circ} \mathrm{C}$ 及び初期 $\mathrm{pH} 4$ で最高の分解率を示したことか ら，小麦フスマ中の蛋白質の分解特性はゼラチンとは 異なると推察された。

また溶解性，不溶性蛋白質濃度については，溶解性

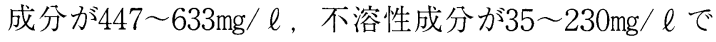
あることが明らかとなった。特に $25^{\circ} \mathrm{C}$ 及び初期 $\mathrm{pH} 7$, $35^{\circ} \mathrm{C}$ 及び初期 $\mathrm{pH} 4 ， 5 ， 45^{\circ} \mathrm{C}$ 及び初期 $\mathrm{pH} 4 ， 7$ では不

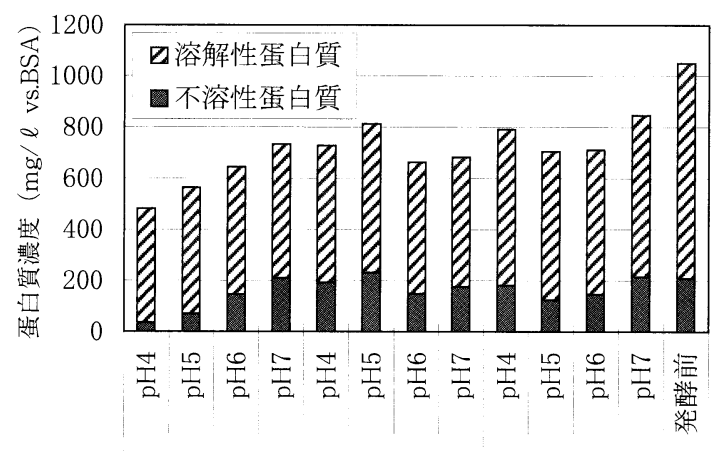

$25^{\circ} \mathrm{C}$

$35^{\circ} \mathrm{C}$

$45^{\circ} \mathrm{C}$

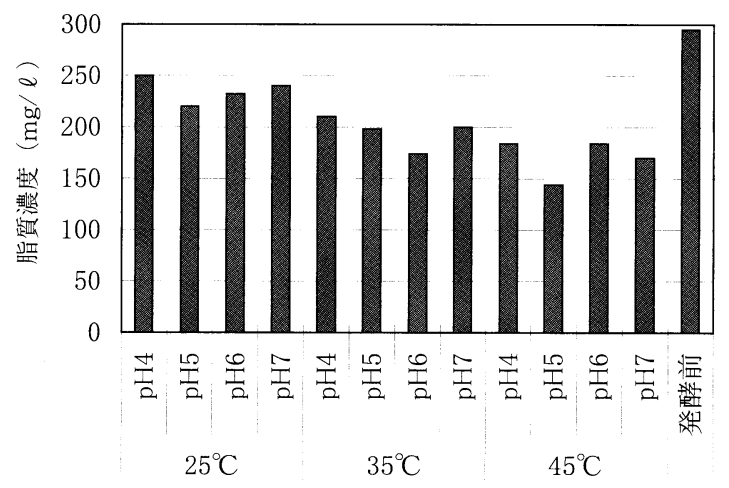

図-7 培養液中の蛋白質 , 脂質濃度

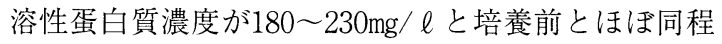
度残存していた。

代表的な水素生成菌である Clostridium 属の微生物 の中にはアミノ酸を分解するものもいるが，グリシン が存在するとスティックランド反応にて水素を消費す るので，蛋白質の分解反応は水素生成に必ずしも有利 に働かないとされる ${ }^{13)}$. 本研究での培養液中の優占種 
については特定していないが, Okamoto らの研究 ${ }^{14)}$ によれば蛋白質を多く含む基質である卵からの水素収 率は最大 $7.1 \mathrm{~m} \ell / \mathrm{g}-\mathrm{VS}$ と示されており，また本研究で の全蛋白質の消費量が最大 $569 \mathrm{mg}$ であることから，こ れらを勘案すると本研究での蛋白質の水素生成への直 接的な寄与は小さいと推察された.

(3) 脂質分析結果

図ー 7 に発酵前及び発酵終了後の培養液中の脂質分 析結果を示す。これより，培養温度の上昇とともに分 解率が上昇し， $45^{\circ} \mathrm{C}$ 及び初期 $\mathrm{pH} 5$ において最も高い 分解率 (51.2\%) を示すことが明らかとなった。 また それぞれの培養温度において, $25^{\circ} \mathrm{C}$ 及び初期 $\mathrm{pH} 5$, $35^{\circ} \mathrm{C}$ 及び初期 $\mathrm{pH} 6,45^{\circ} \mathrm{C}$ 及び初期 $\mathrm{pH} 5$ で分解率が最 大となることが明らかとなった。

Okamoto らの研究によれば脂質を多く含む基質で ある鳥皮からの水素収率は最大 $10.2 \mathrm{ml} / \mathrm{g}-\mathrm{VS}$ と示され ており ${ }^{14)}$ ，また本研究での脂質の消費量が最大 $151 \mathrm{mg}$ であることから，これらを勘案すると本研究での脂質 の水素生成への直接的な寄与は小さいと推察された.

\section{4. まとめ}

本研究では, 神奈川県内の小麦製粉事業者から入手 した小麦フスマを基質として, 植菌せずに初期 $\mathrm{pH}$ を $4,5,6,7$, 培養温度を $25,35,45^{\circ} \mathrm{C}$ と段階的に設 定して回分培養試験を実施し, 初期 $\mathrm{pH}$ 及び培養温度 の水素生成や小麦フスマ成分の分解性に対する影響を 検討した，その結果，以下の知見を得た。

(1)水素収率は, $25^{\circ} \mathrm{C} 及 ひ ゙$ 初期 $\mathrm{pH} 6$ において $80.4 \mathrm{ml} /$ g-VS と最大值を示した。 また実験結果に対して Gompertz型式を当てはめて水素生成ポテンシャル, 最大水素生成速度, 遅滞時間のそれぞれのパラメー 夕を決定した。

(2)小麦フスマの成分である全炭水化物については,

$35^{\circ} \mathrm{C}$ 及び初期 $\mathrm{pH} 7$ において最も高い分解率 $(89.2 \%)$ を示した。また炭水化物消費量と水素生成量間は概 称相関があり, 炭水化物の分解の水素生成への直接 的な関与が示唆された。 また小麦フスマの成分であ る全蛋白質については培養温度の低下とともに分解 率が上昇し， $25^{\circ} \mathrm{C}$ 及び初期 $\mathrm{pH} 4$ において最も高い 分解率 (54.1\%) を示した. さらに小麦フスマの成 分である脂肪については培養温度の上昇とともに分
解率が上昇し， $45^{\circ} \mathrm{C}$ 及び初期 $\mathrm{pH} 5$ において最も高 い分解率 (51.2\%) を示した。

(3)発酵終了後の培養液中には主として酢酸, 酪酸が蓄 積しており，環境保全の観点から，これら有機酸の 処理が今後の課題として残された。

謝辞：本研究を進めるにあたり，貴重なご意見，ご指 導をいただきました株荏原総合研究所生物研究室 宮晶子室長に厚く御礼を申し上げます。

\section{参考文献}

1 ) 田口文章, 矢野玲子：小麦フスマからの水素ガスの自然 発生, 廃棄物学会論文誌, 第14卷, 第 6 号, pp.27-31 (2003)

2 ) 社日本下水道協会: 下水試験方法 (1997)

3 ) J. H. Wu and C. Y. Lin:Biohydrogen production by mesophilic fermentation of food waste-water, Wat. Sci. Tech., Vol. 49, No. 5-6, pp. 223-228 (2004)

4 ) M. -D. Bai, S. -S. Cheng and Y. -C. Chao:Effect of substrate components on hydrogen fermentation of multiple substrates, Wat. Sci. Tech., Vol. 50, No. 8, pp. 209-216 (2004)

5 ) V. A. Vavilin, S. V. Rytow and L. Y. Lokshina:Modeling hydrogen partial pressure change as a result of competition between the butyric and propionic group of acidogenic bacteria, Biores. Technol., Vol. 54, No. 2, pp. 171-177 (1995)

6 ) 河野孝志, 和田克士, 李 玉友, 野池達也 : 複合基質加 らの嫌気性水素発醋に及ぼす基質濃度と $\mathrm{pH}$ の影響, 水 環境学会誌，第27巻，第 7 号, pp. 473-479 (2004)

7 ) A. M. Breure, and J. G. Andel, :Hydrolysis and acidogenic fermentation of a protein, gelatin, in an anaerobic continuous culture, Appl. Microbiol. Biotechnol., Vol. 20, No. 1, pp. 40-45 (1984)

8 ) 水野修, 大原健史, 新谷真史, 野池達也: 水素発醭に㧍 ける有機性廃棄物の分解特性, 環境工学研究論文集, 第 36巻, pp. 423-429 (1999)

9 ) 鈴木智雄: 微生物工学技術ハンドブック, 朝倉書店 (1990)

10) O. Mizuno, M. Shinya, T. Ohara and T. Noike: Characteristics of hydrogen production from bean crud manufacturing waste by anaerobic microflora, Wat. Sci. Tech., Vol. 42, No. 3-4, pp. 345-350 (2000)

11）大下信子, 松本寿美, 土肥哲哉, 竹本裕, 品田司: 食品 系廃充物の水素発酵条件に関する研究，用水と廃水，第 46巻，第12号, pp. 1058-1064 (2004)

12）谷生重晴: 微生物の水素発生メカニズムとバイオ技術を 利用した水素生産, 化学装置, 第33巻, 第 6 号, pp. 104-109 (1991)

13) M. Nagase and T. Matsuo:Interactions between aminoacid-degrading bacteria and methanogenic bacteria in anaerobic digestion, Biotech. Bioeng., Vol. 26, No. 10, pp. 2227-2239 (1982)

14) M. Okamoto, T. Miyahara, O. Mizuno and T. Noike: Biological hydrogen potential of materials characteristic of the organic fraction of municipal solid wastes, Wat. Sci. Tech., Vol. 41, No. 3, pp. 25-32 (2000) 


\title{
Influence of initial pH and temperature on hydrogen fermentation of wheat bran
}

\author{
Hisanori WATANABE, Hidekichi YOSHINO
}

\section{ABSTRACT}

Batch experiments for the hydrogen fermentation using wheat bran of a Flour Company in Kanagawa prefecture under various conditions of temperatures $\left(25^{\circ} \mathrm{C}, 35^{\circ} \mathrm{C}, 45^{\circ} \mathrm{C}\right)$ and initial pHs $(4,5,6,7)$ were conducted without seed sludge.

The results showed that the maximum hydrogen productivity reached $80.4 \mathrm{mg} / \mathrm{g}$-VS under both conditions of temperature $25^{\circ} \mathrm{C}$ and initial $\mathrm{pH} 6$.

Analyzing components of liquors under various experiment conditions, we found the following maximum degradation efficiencies; carbohydrates reached $89.2 \%$ at $35^{\circ} \mathrm{C}$ and initial $\mathrm{pH}$, proteins reached $54.1 \%$ at $25^{\circ} \mathrm{C}$ and initial $\mathrm{pH} 4$, lipids reached $51.2 \%$ at $45^{\circ} \mathrm{C}$ and initial $\mathrm{pH} 5$.

Key Words : wheat bran, hydrogen fermentation, initial $\mathrm{pH}$, temperature, resolution rate

\section{「有害物質制御」産学協同シンポジウム}

主 催 : 大阪産業大学

日 時: 平成18年11月30日 (木)

場＼cjkstart所：天満研修センター（大阪市北区錦町 2-21, TEL : 06-6354-1927)

参 加 者: 大学, 自治体, 企業関係者など200名 を予定

参 加 費: 無料

問い合わせ : 大阪産業大学産業研究所

TEL : 072-875-3001（代）

スケジュール :

午前の部 研究成果報告会 $(10: 00 \sim)$

文部科学省私立大学学術研究高度化推進事業 - 産学連携推進事業

「地域産業創生型有害物質新制御システムの 開発に関する研究」

全体報告

研究成果報告ープロジェクトの概要

成果報告

報告内容: 有害物質分離 - 濃縮法, 有害物質 分解法
午後の部 シンポジウム「有害物質の制御」(13：00～)

開会挨拶 寺島 泰 (大阪産業大学新産業研 究開発センター長)

講演 1 「バイオレメディエーションにおける 微生物リスクの管理」

藤田正憲（高知工業高等専門学校校長）

講演 2 「環境污染物質の毒性メカニズムー細 胞内分子反応の撹乱」

松井三郎 (京都大学地球環境学大学院地球 環境学堂教授)

講演 3 「有害化学物質の環境基準設定のため の健康リスクの考え方」

内山㒈雄 (京都大学大学院工学研究科教授)

講演 4 大島輝夫 (日本リスク研究学会理事)

講演 5 「廃棄物処理・リサイクル分野の有害 物質の施策」

由田秀人（環境省廃棄物・リサイクル対策 部長)

総合討論

情報交換会（17：45～） 